\title{
Comparison of photoautotrophic and mixotrophic cultivation of microalgae Messastrum gracile (Chlorophyceae) in alternative culture media
}

\author{
L. H. Sipaúba-Tavares ${ }^{a *}$ (D), B. Scardoeli-Truzzi ${ }^{a}$ (D), D. C. Fenerick ${ }^{a}$ (D) and M. G. Tedesque ${ }^{a}$ \\ ${ }^{a}$ Centro de Aquicultura, Universidade Estadual Paulista - UNESP, Via de Acesso Prof. Paulo Donato Castellane, s/n, \\ CEP 14884-900, Jaboticabal, SP, Brasil \\ *e-mail: lucia.sipauba@unesp.br
}

Received: July 24, 2019 - Accepted: July 30, 2019 - Distributed: November 30, 2020

(With 3 figures)

\begin{abstract}
Growth and biological conditions of Messastrum gracile were evaluated to compare the effect of photoautotrophic and mixotrophic cultivation on the increase of biomass production and chemical conditions cultured in macrophyte and commercial culture media. The growth rate $(\mathrm{k})$ of $M$. gracile was different in the culture media, higher in mixotrophic cultivation for Lemna minor culture medium, whilst to Eichhornia crassipes and NPK culture media were higher in photoautotrophic cultivation. Mean lipid contents in photoautotrophic cultivation were $8.2 \%$ biomass dry weight, whereas they reached $19 \%$ biomass dry weight in mixotrophic cultivation. Protein contents were below $48 \%$ biomass dry weight in photoautotrophic cultivation and 30\% biomass dry weight in mixotrophic cultivation. Messastrum gracile cultured in macrophyte culture media (E. crassipes and L. minor) and NPK culture medium provided satisfactory results with regard to lipid and protein contents in mixotrophic and photoautotrophic cultivations, respectively. Lipid and protein contents in alternative media were higher or similar to the $\mathrm{CHU}_{12}$ commercial culture medium.
\end{abstract}

Keywords: macrophytes, inorganic fertilizer, sugarcane molasses, growth.

\section{Comparação dos cultivos foto-autotrófico e mixotrófico da microalga Messastrum gracile (Chlorophyceae) em meios de cultura alternativos}

\begin{abstract}
Resumo
O crescimento e as condições biológicas da microalga Messastrum gracile foram avaliados para comparar o efeito do cultivo foto-autotrófico e mixotrófico na produção de biomassa e condições químicas em meios de cultura comercial e de macrófitas. A taxa de crescimento (k) de M. gracile foi diferente entre os meios de cultura, sendo maior no cultivo mixotrófico para o meio Lemna minor, enquanto para os meios Eichhornia crassipes e NPK foram maiores no cultivo foto-autotrófico. Os teores de lipídios no cultivo foto-autotrófico foram de $8,2 \%$ da biomassa seca, enquanto que no mixotrófico atingiram $19 \%$ da biomassa seca. Os teores de proteína em cultivo foto-autotrófico estiveram abaixo de $48 \%$ da biomassa seca e 30\% de biomassa seca no cultivo mixotrófico. Messastrum gracile cultivada em meios de cultura de macrófitas (E. crassipes e L. minor) e NPK apresentaram resultados satisfatórios em relação aos teores de lipídeos e proteínas nos cultivos mixotróficos e foto-autotróficos, respectivamente. Os teores lipídicos e proteicos em meios alternativos foram maiores ou semelhantes ao meio comercial $\mathrm{CHU}_{12}$.
\end{abstract}

Palavras-chave: macrófitas, fertilizante inorgânico, melaço da cana de açúcar, crescimento.

\section{Introduction}

One of the important points in microalgae cultivation is production cost and the quality of the biomass generated. In fact, aquatic plants and inorganic fertilizers as culture media and sugarcane molasses as organic carbon source may generate best yields using products considered aquaculture waste (aquatic plants) and agricultural industry (sugarcane molasses). Alternative cheap carbon sources such as industrial by-product sugarcane molasses (50\% w/w total sugar), may replace glucose (Gaurav et al.,
2016). Molasses is a sticky brown fluid obtained from the crystallization of sugar after the removal of most of the sucrose from the sugarcane juice (Mondal et al., 2017).

Photoautotrophic growth of microalgae requires light, $\mathrm{CO}_{2}$, water and nutrients to yield a biomass rich in lipids, protein and sugars. However, some microalgae species have also the peculiar capability to growing in mixotrophic mode, where the autotrophic metabolism is integrated with heterotrophic metabolism that oxidizes the reduced carbon 
source available in the culture medium. However, in case of some microalgae, the photosynthetic efficiency may be reduced in mixotrophic cultivation (Cecchin et al., 2018).

The assimilations organic carbon, nutrients and $\mathrm{CO}_{2}$ simultaneously perform respiration and photosynthesis in mixotrophic cultivation system (Cheah et al., 2018). Energy needs for carbon reduction under such growth conditions are derived from organic carbon and light harvested (Wen et al., 2019). Although growth rate and biomass production for some microalgae in mixotrophic condition may be several times higher than those in a photoautotrophic condition, however the synthesis of metabolic products are affected by the quality and quantity of organic carbon (Choi and Lee, 2015).

Light energy and chemical energy act together to increase the biomass concentration in the cultivation. It has been reported that lipid metabolism in microalgae is affected by changes in carbon source, light intensity and photoperiods (Mondal et al., 2017).

Biomass and oil accumulation in microalgae may be enhanced by adding supplementary nutrients to culture medium. Lowering the cost of microalgae production in expensive carbon source is more desirable than refined glucose. Consequently, the use of sugarcane-extracted molasses has been identified as a promising carbon source for microalgae mixotrophic cultivation (Nguyen et al., 2018). The ability of microalgae to transit from photoautotrophic to mixotrophic growth is a phenomenon that exists in a number of genera and species throughout the major taxonomic division. Many algal organisms may use either autotrophic or heterotrophic metabolic processes for growth (Choi and Lee, 2015).

Several environmental and operational factors may affect microalgae biomass productivity, biomass composition and photosynthetic performance of microalgae. Nitrogen and phosphorus are important nutrients for the production of microalgae biomass and mixotrophic cultivation may greatly enhance microalgae growth with various nitrogen sources. In fact, the biochemical composition of microalgae is crucial in the application of several processes (Li et al., 2019).

Messastrum gracile (Reinsch) T.S.Garcia a freshwater green microalga, proved to be a good source of fish food due to its fast growth and easy cultivation (Sipaúba-Tavares and Braga, 2007). Although, Chlorophyceae may be used in mixotrophic cultivation, more strains must be evaluated for cultivation with sugarcane molasses carbon sources, such as M. gracile, since studies developed on microalgae are scarce. Current research compares photoautotrophic growth of $M$. gracile with its mixotrophic growth in the presence of sugarcane molasses as carbon source in different alternative culture media. Research investigated the influence of mixotrophic and photoautotrophic growth using different culture media to enhance biomass, protein and lipid contents.

\section{Material and Methods}

\subsection{Algal strain and culture conditions}

Microalgae Messastrum gracile (CCMA-UFSCar5) was used to observe the effects on growth by different culture media under photoautotrophic and mixotrophic cultivations. Algae were batch-cultured at $22 \pm 2{ }^{\circ} \mathrm{C}$ and exposed to light at $60 \mu \mathrm{mol} \mathrm{m} \mathrm{m}^{-2} \mathrm{~s}^{-1}$ in a 24-h light cycle. Four culture media were used, namely, one commercial medium $\mathrm{CHU}_{12}$ and three alternative media, one with inorganic fertilizer NPK (20-5-20) (Sipaúba-Tavares and Rocha, 1993) and two macrophyte culture media with the aquatic plants Eichhornia crassipes (EC) and Lemna minor (LM) (Sipaúba-Tavares et al., 2009, 2018). The experiment started at a density of $2.5 \times 10^{5}{\text { cells } \mathrm{mL}^{-1}}^{-1}$ containing commercial, inorganic fertilizer and macrophyte culture media with continuous air bubbling. Continuous illumination was applied and the alternatives and commercial culture media were employed to grow the microalgae cultures in 2 L. Cell growth was evaluated in triplicate $(n=3)$ for 28 days, in all treatments.

\subsection{Treatment with sugarcane molasses}

Sugarcane molasses $\left(82.62^{\circ} \mathrm{BX}\right)$, as organic carbon source with pH 5.9 was obtained from Brazilian Molasses Ltda (Brazil) and used for mixotrophic cultivation. Sugarcane molasses contained $20 \%$ water, $8 \%$ fructose, $7 \%$ glucose and metal ions, such as calcium, potassium, sodium, iron, magnesium, copper, and others. Crude molasses were diluted in distilled water and autoclaved at $1 \mathrm{~atm}$, for 30 minutes. The solution was subsequently used in assays for mixotrophic cultivation. Further, $1.5 \mathrm{~g} \mathrm{~L}^{-1}$ concentration of sugarcane molasses was added to the culture media. The use of this concentration was determined in a preliminary experiment to avoid the inhibitory effect on biomass and lipid content.

\subsection{Biomass estimation and biochemical analyses}

Cell growth was monitored for 28 days. Triplicate $1 \mathrm{~mL}$ aliquots were removed daily from the microalgae culture and $2 \times 1 \mathrm{~mL}$ sub-samples were used for cell quantification by a Neubauer haemocytometer. Growth rate $(\mathrm{k})$ was calculated by the formula $\mathrm{k}=\left(3.322 / \mathrm{t}_{2}-\mathrm{t}_{1} \times \log \mathrm{N}_{2} / \mathrm{N}_{1}\right)$, where: $\mathrm{t}=$ time, $\mathrm{N}=$ number of cells and subscripts denote rates at different times (Guillard, 1973). Doubling time (cell division time or generation time) was calculated from results obtained from growth rate, by formula DT $=1 \mathrm{k}^{-1}$ where: DT $=$ doubling time and $1 \mathrm{k}^{-1}=$ division per days (Guillard, 1973). Cell volume was calculated by mean cell size with the use of the most appropriate geometric form, or rather two coupled cone formula in the case of $M$. gracile (Hillebrand et al., 1999). Total organic carbon (TOC) was calculated by regression following Rocha and Duncan (1985), TOC $=0.1204 \mathrm{~V}^{1.051}$ where: $\mathrm{TOC}=$ total organic carbon content in pg cell ${ }^{-1}$ and $\mathrm{V}=$ cell volume. Microalgae biomass was harvested, centrifuged and lyophilized for analysis of total lipid contents (AOAC, 2012) and protein contents by Dumas combustion method, supplied by Leco (CN628). Protein and lipid contents were analyzed on the first ( $1^{\text {st }}$-day) and last $\left(28^{\text {th }}\right.$-day) day of the experiment. Chlorophyll- $a$ concentration was determined extracting pigments with alcohol $90 \%$ and reading spectrophotometer (663nm and $750 \mathrm{~nm}$ ) and was processed according to the methodology presented by Nusch (1980).

\subsection{Physical and chemical parameters of culture media}

Physical and chemical parameters of culture media were performed weekly. Dissolved oxygen (DO), $\mathrm{pH}$ and conductivity $(\mathrm{CO})$ of culture media were measured 
with YSI 556 MPS multi-sensor. Total phosphorous (TP) and total inorganic nitrogen (TIN) were quantified by spectrophotometry, following Golterman et al. (1978) and Koroleff (1976). Analyses were performed immediately after sampling or samples were duly stored under refrigeration.

\subsection{Statistical analyses}

All data underwent one-way analysis of variance (ANOVA) with Statistica 8.0 to test the effects between microalga culture media and also for two cultivation conditions (StatSoft, 2007). Tukey's test was applied when differences between culture media occurred. Differences were considered significant at $\mathrm{p}<0.05$. All experiments were carried out in triplicate.

\section{Results}

Highest cell density was obtained in macrophyte culture media in photoautotropphic cultivation, with $505 \times 10^{5}$ cell $\mathrm{mL}^{-1}(\mathrm{LM})$ and $530 \times 10^{5}$ cell $\mathrm{mL}^{-1}$ (EC) on final growth (28 $8^{\text {th }}$-day). However, cell density of M. gracile in NPK and in macrophytes (EC and LM) culture media in photoautotrophic cultivation was two (LM) or thirty (NPK) times higher than that in mixotrophic cultivation. All cells died on the $18^{\text {th }}$-day of the experiment in the NPK culture medium in mixotrophic cultivation (Figure 1). Mean cell density in photoautotrophic cultivation was higher when $M$. gracile was cultured with LM culture medium $\left(277 \times 10^{5} \mathrm{cell} \mathrm{mL}^{-1}\right)$ and in mixotrophic cultivation when cultured with $\mathrm{CHU}_{12}$ culture medium $\left(135 \times 10^{5} \mathrm{cell}^{\mathrm{mL}} \mathrm{L}^{-1}\right)$ (Figure 1, Table 1).

The growth rate $(\mathrm{k})$ of $M$. gracile was different between culture media. It was higher in mixotrophic cultivation for LM culture medium. However, for NPK and EC culture media were higher in photoautotrophic cultivation. Until the $14^{\text {th }}$-day, the growth rate in commercial medium it was higher in mixotrophic culture medium. The values of $\mathrm{k}$ were lower in NPK and higher in the macrophyte culture media (EC and LM) (Figure 1). Doubling time was different between culture media and cultivation
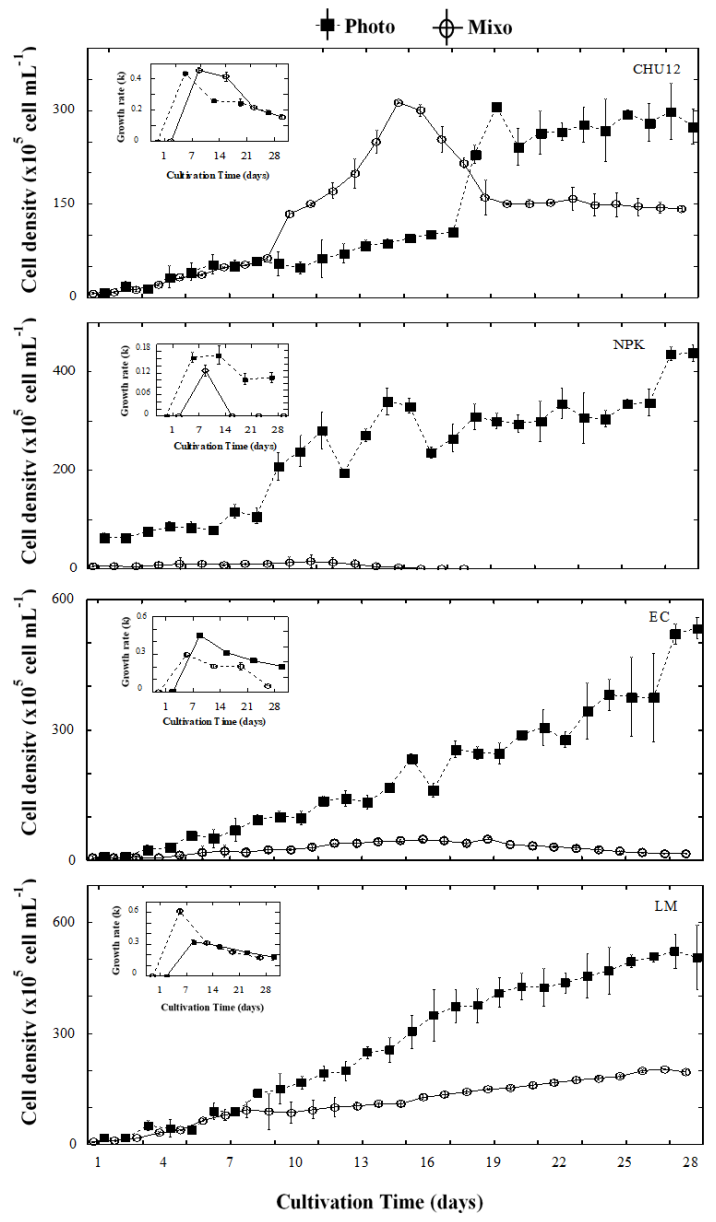

Figure 1. Cell density and growth rate of Messastrum gracile in photoautotrophic (Photo) and mixotrophic (Mixo) cultivations in different culture media: $\mathrm{CHU}_{12}$, NPK, Eichhornia crassipes (EC) and Lemna minor (LM). Error bars show the standard deviations of at least three measurements.

Table 1. Mean and standard deviation of variables (microalgae and culture media) measured in photoautotrophic and mixotrophic cultivations.

\begin{tabular}{|c|c|c|c|c|c|c|c|c|c|}
\hline \multirow[t]{2}{*}{ Variables } & \multicolumn{4}{|c|}{ Photoautotrophic } & \multicolumn{4}{|c|}{ Mixotrophic } & \multirow[t]{2}{*}{ Anova } \\
\hline & $\mathrm{CHU}_{12}$ & NPK & EC & LM & $\mathrm{CHU}_{12}$ & NPK & EC & LM & \\
\hline \multicolumn{10}{|l|}{ Microalgae } \\
\hline DT (days) & $3.3^{\mathrm{b}}$ & $9.3^{\mathrm{a}}$ & $5^{\mathrm{a}}$ & $5^{\mathrm{a}}$ & $2.7^{\mathrm{a}}$ & $9.1^{\mathrm{c}}$ & $6.4^{\mathrm{b}}$ & $5.5^{\mathrm{b}}$ & $*$ \\
\hline $\operatorname{MD}\left(\times 10^{5} \mathrm{~mL}^{-1}\right)$ & $143^{\mathrm{b}}$ & $241^{\mathrm{a}}$ & $203^{\mathrm{a}}$ & $277^{\mathrm{a}}$ & $135^{\mathrm{a}}$ & $7^{\mathrm{c}}$ & $27^{\mathrm{c}}$ & $115^{\mathrm{b}}$ & * \\
\hline $\mathrm{CV}\left(\mu \mathrm{m}^{-3}\right)$ & $68 \pm 35^{a}$ & $57 \pm 28^{a}$ & $20 \pm 5^{\mathrm{b}}$ & $11 \pm 3^{\mathrm{b}}$ & $13 \pm 5^{\mathrm{a}}$ & $5 \pm 2^{b}$ & $6 \pm 1^{\mathrm{ab}}$ & $4 \pm 0.6^{b}$ & $*$ \\
\hline \multicolumn{10}{|l|}{ Medium } \\
\hline TIN (mg L-1) & $1.1 \pm 0.8^{\mathrm{b}}$ & $1.5 \pm 0.2^{\mathrm{ab}}$ & $1.7 \pm 0.5^{\mathrm{a}}$ & $0.9 \pm 0.4^{b}$ & $2.2 \pm 1.1^{\mathrm{b}}$ & $4.6 \pm 0.6^{\mathrm{a}}$ & $1.4 \pm 0.2^{\mathrm{b}}$ & $0.5 \pm 0.2^{\mathrm{c}}$ & $*$ \\
\hline $\mathrm{TP}\left(\mathrm{mg} \mathrm{L}^{-1}\right)$ & $1.1 \pm 0.1^{\mathrm{c}}$ & $1.6 \pm 0.1^{\mathrm{a}}$ & $1.3 \pm 0.1^{\mathrm{b}}$ & $1.1 \pm 0.1^{\mathrm{c}}$ & $1.0 \pm 0.3^{\mathrm{b}}$ & $1.7 \pm 0.1^{\mathrm{a}}$ & $0.9 \pm 0.1^{\mathrm{b}}$ & $0.3 \pm 0.1^{\mathrm{c}}$ & $*$ \\
\hline $\mathrm{DO}\left(\mathrm{mg} \mathrm{L}^{-1}\right)$ & $7.4 \pm 0.3^{\mathrm{b}}$ & $8.7 \pm 0.3^{\mathrm{a}}$ & $7.2 \pm 0.2^{\mathrm{b}}$ & $7.1 \pm 0.6^{\mathrm{b}}$ & $6.8 \pm 0.4^{\mathrm{a}}$ & $6.2 \pm 0.4^{\mathrm{a}}$ & $6.4 \pm 0.8^{\mathrm{a}}$ & $6.4 \pm 1.3^{\mathrm{a}}$ & $*$ \\
\hline $\mathrm{CO}\left(\mathrm{mS} \mathrm{cm}^{-1}\right)$ & $0.6 \pm 0.1^{\mathrm{b}}$ & $1.6 \pm 0.1^{\mathrm{a}}$ & $0.6 \pm 0.1^{\mathrm{bc}}$ & $0.4 \pm 0.1^{\mathrm{c}}$ & $0.9 \pm 0.1^{\mathrm{b}}$ & $1.5 \pm 0.1^{\mathrm{a}}$ & $0.6 \pm 0.1^{\mathrm{c}}$ & $0.6 \pm 0.1^{\mathrm{c}}$ & $*$ \\
\hline $\mathrm{pH}$ & $8.5 \pm 2.2^{\mathrm{a}}$ & $8.6 \pm 0.3^{\mathrm{a}}$ & $9.3 \pm 1.8^{\mathrm{a}}$ & $8.7 \pm 0.8^{\mathrm{a}}$ & $9.3 \pm 2.4^{\mathrm{a}}$ & $8.7 \pm 3.1^{\mathrm{a}}$ & $10 \pm 1.2^{\mathrm{a}}$ & $8.2 \pm 0.1^{\mathrm{a}}$ & ns \\
\hline
\end{tabular}

Means in each row, followed by the same letter, do not significantly differ $(\mathrm{p}<0.05)$ in the culture media of each cultivation. ANOVA (test) between photoautotrophic and mixotrophic cultivations. DT = doubling time; $\mathrm{MD}=$ mean density; $\mathrm{CV}=$ cell volume; $\mathrm{TIN}=$ total inorganic nitrogen; $\mathrm{TP}=$ total phosphorus; $\mathrm{DO}=$ dissolved oxygen $; \mathrm{CO}=$ conductivity; $\mathrm{EC}=$ Eichhornia crassipes; $\mathrm{LM}=$ Lemna minor $; \mathrm{ns}=$ not significant; $* \mathrm{p}<0.05$. 
conditions were faster in $\mathrm{CHU}_{12}$ with 2.7 days in mixotrophic cultivation and 3.3 days in photoautotrophic condition, but slower in NPK with 9.1 days in mixotrophic and 9.3 days in photoautotrophic cultivation. In case of macrophyte culture media, doubling time was faster in photoautotrophic condition. Cell volume of M. gracile was higher in photoautotrophic cultivation and different between culture media in the two cultivation conditions. However, it was higher in $\mathrm{CHU}_{12}$ culture medium, with $68 \pm 35 \mu \mathrm{m}^{3}$ and $13 \pm 5 \mu \mathrm{m}^{3}$ for photoautotrophic and mixotrophic cultivations, respectively (Table 1).

Chlorophyll- $a$ was highest in photoautotrophic than in mixotrophic cultivation ranging between $0.4 \mathrm{~g} \mathrm{~L}^{-1}$ ( $1^{\text {st }}$-day) and $1.3 \mathrm{~g} \mathrm{~L}^{-1}$ (28 $8^{\text {th }}$-day) in $\mathrm{CHU}_{12} ; 0.6 \mathrm{~g} \mathrm{~L}^{-1}$ (1 $1^{\text {st }}$-day) and $2.2 \mathrm{~g} \mathrm{~L}^{-1}$ (21 $1^{\text {st }}$-day) in NPK; $0.3 \mathrm{~g} \mathrm{~L}^{-1}$ (1 $1^{\text {st }}$-day) and $1.5 \mathrm{~g} \mathrm{~L}^{-1}$ (28 $8^{\text {th }}$-day) in EC and $0.5 \mathrm{~g} \mathrm{~L}^{-1}$ (15t-day) and $5.7 \mathrm{~g} \mathrm{~L}^{-1}\left(21^{\text {st }}\right.$-day) in LM culture media during the $M$. gracile growth. Chlorophyll- $a$ in mixotrophic cultivation was below to $0.3 \mathrm{~g} \mathrm{~L}^{-1}$ (Figure 2). Total organic carbon decreased from the $14^{\text {th }}$-day in photoautotrophic cultivation for $\mathrm{CHU}_{12}$ and LM culture media. In photoautotrophic cultivation the TOC ranged between $2.3 \mathrm{pg} \mathrm{cell}^{-1}(\mathrm{EC})$ and $12.2 \mathrm{pg} \mathrm{cell}^{-1}\left(\mathrm{CHU}_{12}\right)$, whilst in mixotrophic cultivation it ranged between $0.2 \mathrm{pg} \mathrm{cell}^{-1}(\mathrm{NPK})$ and $2.9 \mathrm{pg} \mathrm{cell}^{-1}\left(\mathrm{CHU}_{12}\right)$ (Figure 2).
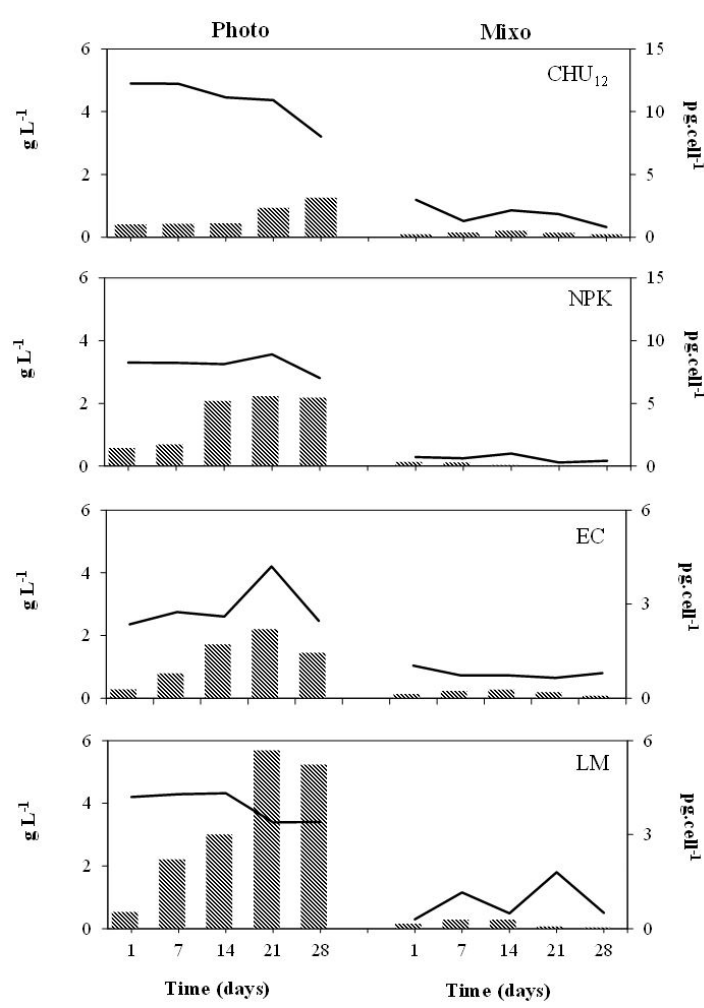

Figure 2. Chlorophyll- $a$ (g L $\mathrm{g}^{-1}$ - bars) and total organic carbon (pg cell ${ }^{-1}$ - line) of Messastrum gracile in photoautotrophic (Photo) and mixotrophic (Mixo) cultivations in different culture media: $\mathrm{CHU}_{12}$, NPK, Eichhornia crassipes (EC) and Lemna minor (LM).
Constant air bubbling kept DO above $6.5 \mathrm{mg} \mathrm{L}^{-1}$ for M. gracile cultured in photoautotrophic cultivation and $5.1 \mathrm{mg} \mathrm{L}^{-1}$ in mixotrophic cultivation, and was different between cultivation conditions. Although, conductivity was higher and different between the two cultivation conditions, highest values were observed in NPK culture medium. Moreover, $\mathrm{pH}$ ranged between $8.5 \pm 2.2\left(\mathrm{CHU}_{12}\right)$ and $9.3 \pm 1.8$ (EC) in photoautotrophic cultivation and between $8.2 \pm 0.1(\mathrm{LM})$ and $10 \pm 1.2$ (EC) in mixotrophic cultivation. There was no difference to $\mathrm{pH}$ between the two cultivation conditions (Table 1).

Nitrogen concentration in NPK culture medium was higher in mixotrophic cultivation with aproximately $4.6 \pm 0.6 \mathrm{mg} \mathrm{L}^{-1}$ and $M$. gracile growth was interrupted on the $18^{\text {th }}$ days, with total cell death. However, microalga could growth in the NPK culture medium with $1.5 \pm 0.6 \mathrm{mg} \mathrm{L}^{-1}$ in photoautotrophic condition. Total inorganic nitrogen and TP concentrations were higher in photoautotrophic cultivation for macrophyte culture media (EC and LM). In the case of NPK culture medium, the compounds were higher in mixotrophic cultivation (Table 1).

Mean lipid contents in photoautotrophic cultivation were $8.2 \%$ biomass dry weight and in mixotrophic cultivation, it was $19 \%$ biomass dry weight. Highest lipid contents in mixotrophic cultivation were found to $M$. gracile cultured in macrophyte culture media with $5.8 \%$ and $2.7 \%$ biomass dry weight in the beginning of growth and $11.7 \%$ and $18.6 \%$ biomass dry weight in the end of the M. gracile growth in EC and LM culture media, respectively (Figure 3 ). Protein contents were below $48 \%$ biomass dry weight $\left(\mathrm{CHU}_{12}\right.$ and NPK) in photoautotrophic cultivation and $30 \%$ biomass dry weight (NPK) in mixotrophic cultivation. In $\mathrm{CHU}_{12}$
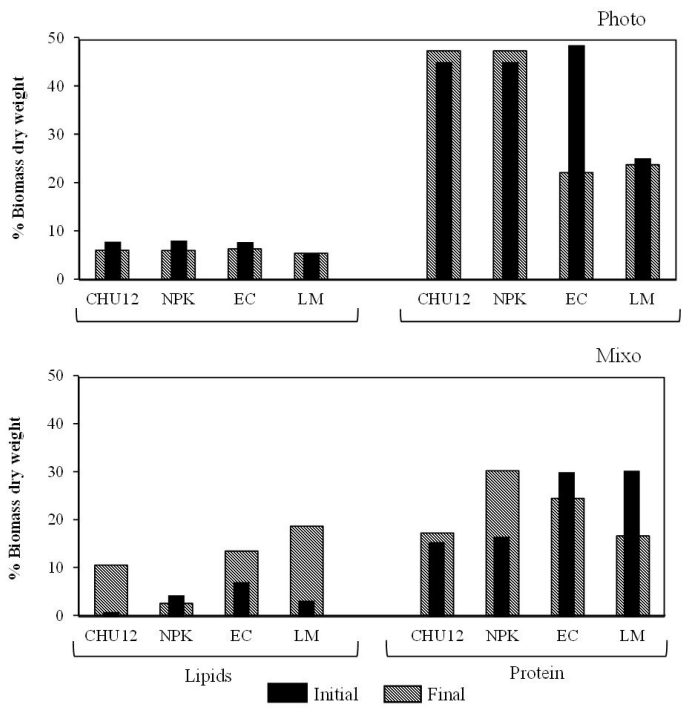

Figure 3. Lipid and protein levels (\% biomass dry weight) in the initial and final of Messastrum gracile growth in photoautotrophic (Photo) and mixotrophic (Mixo) cultivations in different culture media: $\mathrm{CHU}_{12}$, NPK, Eichhornia crassipes (EC) and Lemna minor (LM). 
and NPK culture media, the protein contents were higher at the final of the $M$. gracile growth $\left(28^{\text {th }}\right.$-day), whilst in macrophyte culture media it was higher in the beginning of the $M$. gracile growth ( $1^{\text {st }}$-day) for two cultivation conditions (Figure 3).

\section{Discussion}

Growth cell was higher in photoautotrophic cultivation except in $\mathrm{CHU}_{12}$ medium. The latter was higher until $18^{\text {th }}$-day of the experiment in the mixotrophic cultivation, after which it decreased until the end of the experiment. Consequently, cell density of Messastrum gracile in mixotrophic cultivation decreased when compared to that in photoautotrophic cultivation. Mondal et al. (2017) reported that the growth rate of Chlorella sp. under mixotrophic cultivation was three times higher than that in photoautotrophic condition. Messastrum gracile growth in mixotrophic cultivation was always lower than in photoautotrophic cultivation except $\mathrm{CHU}_{12}$ between the $10^{\text {th }}$ and $18^{\text {th }}$ days. Sugars molasses contains several vitamins and minerals such as potassium, sodium and calcium, similarly to $\mathrm{CHU}_{12}$ culture medium. Consequently, these compounds together help increase biomass production of microalgae. All culture media used after $17^{\text {th }}$ and/or $19^{\text {th }}$ day decrease growth or died (NPK) in mixotrophic cultivation, except in LM that continued to grow, albeit at low cell density. Messastrum gracile in mixotrophic condition did not result in a high biomass when compared to photoautotrophic condition.

Choi and Lee (2015) reported that Botryococcus braunii and Dunaliella sp. had maximum biomass productivity and specific growth rate in mixotrophic cultivation than photoautotrophic condition. Differences in microalgae growth in the culture medium are usually due to protocol employed. Biomass was high in photoautotrophic condition for NPK, EC and LM, whilst growth rate in $\mathrm{LM}$ and $\mathrm{CHU}_{12}$ culture media was higher in mixotrophic cultivation for $M$. gracile growth. Sufficient energy supported nutrients uptake and transport between cell compartments and enhance a better microalgae growth in photoautotrophic condition (Li et al., 2019).

Higher chlorophyll- $a$ concentration was observed in photoautotrophic cultivation with maximum content in LM culture medium with $5.7 \mathrm{~g} \mathrm{~L}^{-1}$. However, in mixotrophic cultivation, EC culture media chlorophyll- $a$ concentration reached $0.3 \mathrm{~g} \mathrm{~L}^{-1}$. The availability of organic carbon generally triggers a decrease in chlorophyll concentration and changes in other pigments (Van Wagenen et al., 2015). The intracellular nitrogen storage pool may be the in form of amino acids, amino compounds, nitrate, ammonium, protein and chlorophyll.

The reserve of certain nutrients, such as nitrogen triggers growth because of the fact that microalgae the ability to incorporate carbon redirecting to glutamate (Wen et al., 2019). Total inorganic nitrogen content in mixotrophic cultivation in $\mathrm{CHU}_{12}$ and NPK culture media was higher than photoautotrophic cultivation, represented in higher protein content in photoautotrophic cultivation and lipid content in mixotrophic cultivation. On the other hand, lipid contents were high or similar to $\mathrm{CHU}_{12}$ medium in macrophyte culture media in mixotrophic cultivation. There was not observed the influence of total nitrogen with lipid contents in the two cultivation conditions. Li et al. (2019) reported that ammonium decreased microalga lipid in photoautotrophic cultivation and increased lipid in mixotrophic cultivation, with inhibition of photosynthetic performance inducing stronger photo-protection, particularly in mixotrophic cultivation. Concentration in which nitrogen compounds may be effectively toxic varies greatly with microalgae species and culture conditions (Li et al., 2019).

Protein contents appeared to be related to the nitrogen availability in the culture medium. Li et al. (2019) reported that $50 \mathrm{mg} \mathrm{L}^{-1}$ of ammonium was not enough to maintain higher protein synthesis. In current experiment the lowest protein contents found in the two cultivation conditions ( $<50 \%$ biomass dry weight) may be associated to lowest nitrogen concentration in the culture media used for M. gracile growth. According to Choi and Lee (2015) slower microalgae growth may result in lower lipid yields when compared to faster growing of microalgae. This revealed that lipid contents were lowest between the culture media used, although highest lipid contents and growth rate in mixotrophic cultivation have been reported in LM culture medium. High biomass productivity is not associated with high lipid contents. Accumulation start after nutrient is used up for biomass growth, such as the nitrogen starvation with improvement in lipid production (Cheah et al., 2018).

Nguyen et al. (2018) reported that concentration of glucose (sugarcane bagasse) influenced the lipid contents in microalgae. However, a further increase in the glucose concentration results in a slight decrease in biomass due to higher glucose content that enhanced accumulation of various metabolized organic acid, with high osmotic pressure and low $\mathrm{pH}$ that inhibit cell growth (Mu et al., 2015).

Phosphorous concentrations in NPK and LM culture media were highest than nitrogen in photoautotrophic cultivation. Fan et al. (2018) reported when phosphorus was occasionally added, the $\mathrm{NO}_{3}-\mathrm{N}$ removal efficiency of the system was improved, due to photoautotrophic and mixotrophic conditions.

The growth of M. gracile in photoautotrophic cultivation had best results when compared with mixotrophic cultivation, mainly regard to NPK, EC and LM culture media. However, the lipid contents were higher in mixotrophic cultivation, mainly at the end of $M$. gracile growth. Doubling time was faster in $\mathrm{CHU}_{12}$ culture medium in mixotrophic cultivation. Sugarcane molasses may be used with carbon source in the growth of $M$. gracile, even though biomass density, TOC, chlorophyll- $a$, protein contents were lower than photoautotrophic cultivation. Evidence suggests that photoautotrophic and mixotrophic cultivations for M. gracile in lab conditions deserve further in-depth studies due to the high biomass difference in the two culture conditions.

Sugarcane molasses is a good tool for the cultivation of microalgae in the tropical regions because it is a cheap 
product and easy to find, especially in our region, coupled to high lipid contents and growth rate $(\mathrm{k})$ in the analyzed cultivation conditions, except in NPK culture medium. Further, macrophyte culture media (E. crassipes and $L$. minor) presented satisfactory results with high lipid contents in mixotrophic cultivation and protein contents in photoautotrophic cultivation. In photoautotrophic cultivation commercial medium $\left(\mathrm{CHU}_{12}\right)$ and NPK were better than macrophyte culture media, except EC culture medium which was high or similar to NPK and $\mathrm{CHU}_{12}$ at the beginning of $M$. gracile growth. Protein and lipid contents in culture media NPK, EC and LM were satisfactory when compared with data in current literature. Macrophyte culture media can also be a tool for the microalga cultivation with cheaper cost production, and their potential use in mixotrophic condition for producing cost-effective microalgae lipid.

\section{Acknowledgements}

The authors would like to thank FAPESP for funding (14/24697-3) and for the scholarship grant to the last author (17/11001-9).

\section{References}

ASSOCIATION OF OFFICIAL ANALYTICAL CHEMISTS - AOAC, 2012. Official method: fatty acids in oils and fats: preparation of methyl esters: boron trifluoride method. In: ASSOCIATION OF OFFICIAL ANALYTICAL CHEMISTS - AOAC. Official methods of analysis of AOAC International. 19th ed. Gaithersburg: AOAC International.

CECCHIN, M., BENFATTO, S., GRIGGIO, F., MORI, A., CAZZANIGA, S., VITUlO, N., DELLEDONNE, M. and BALLOTTARI, M., 2018. Molecular basis of autotrophic vs mixotrophic growth in Chlorella sorokiniana. Scientific Reports, vol. 8, no. 1, pp. 6465. http://dx.doi.org/10.1038/s41598-01824979-8. PMid:29691462.

CHEAH, W.Y., SHOW, P.L., JUAN, J.C., CHANG, J.S. and LING, T.C., 2018. Enhancing biomass and lipid productions of microalgae in palm oil mill effluent using carbon and nutrient supplementation. Energy Conversion and Management, vol. 164, pp. 188-197. http://dx.doi.org/10.1016/j.enconman.2018.02.094.

CHOI, H.J. and LEE, S.M., 2015. Biomass and oil content of microalgae under mixotrophic conditions. Environmental Engineering Research, vol. 20, no. 1, pp. 25-32. http://dx.doi. org/10.4491/eer.2014.043.

FAN, C., WANG, P., ZHOU, W., WU, S., HE, S., HUANG, J. and CAO, L., 2018. The influence of phosphorus on the autotrophic and mixotrophic denitrification. The Science of the Total Environment, vol. 643, pp. 127-133. http://dx.doi.org/10.1016/j. scitotenv.2018.06.185. PMid:29936156.

GAURAV, K., SRIVASTAVA, R., SHARMA, J.G., SINGH, R. and SINGH, V., 2016. Molasses-based growth and lipid production by Chlorella pyrenoidosa: a potential feedstock for biodiesel. International Journal of Green Energy, vol. 13, no. 3, pp. 320-327. http://dx.doi.org/10.1080/15435075.2014.966268.

GOLTERMAN, H.L., CLYMO, R.S. and OHMSTAD, M.A.M., 1978. Methods for physical and chemical analysis of fresh water. 2nd ed. Oxford: Blackwell Scientific Publications, 213 p. IBP Handbook, no. 8.

GUILLARD, R.R.L., 1973. Division rates. In: J.R. STEIN, ed. Handbook of phycological methods: culture methods and growth measurements. London: Cambridge University Press, pp. 289-311.

HILLEBRAND, H., DÜRSELEN, C.D., KIRSCHTEL, D., POLLINGHER, U. and ZOHARY, T., 1999. Biovolume calculation for pelagic and benthic microalgae. Journal of Phycology, vol. 35, no. 2, pp. 403-424. http://dx.doi.org/10.1046/j.15298817.1999.3520403.x.

KOROLEFF, F., 1976. Determination of nutrients. In: E. GRASHOF and E. KREMLING, eds. Methods of seawater analysis. German: Verlag Chemie Wenhein, pp. 126-133.

LI, X., LI, W., ZHAI, J., WEI, H. and WANG, Q., 2019. Effect of ammonium nitrogen on microalgal growth, biochemical composition and photosynthetic performance in mixotrophic cultivation. Bioresource Technology, vol. 273, pp. 368-376. http:// dx.doi.org/10.1016/j.biortech.2018.11.042. PMid:30453251.

MONDAL, M., GHOSH, A., TIWARI, O.N., GAYEN, K., DAS, P., MANDAL, M.K. and HALDER, G., 2017. Influence of carbon source and light intensity on biomass and lipid production of Chlorella sorokiana BTA 9031 isolated from coalfield under various nutritional modes. Energy Conversion and Management, vol. 145, pp. 247-254. http://dx.doi.org/10.1016/j.enconman.2017.05.001.

MU, J., LI, S., CHEN, D., XU, H., HAN, F., FENG, B. and LI, Y., 2015. Enhanced biomass and oil production from sugarcane bagasse hydrolysate (SBH) by heterotrophic oleaginous microalgae Chlorella protothecoides. Bioresource Technology, vol. 185, pp. 99-105. http://dx.doi.org/10.1016/j.biortech.2015.02.082. PMid:25768412.

NGUYEN, H.C., SU, C.H., YU, Y.K. and HUONG, D.T.M., 2018. Sugarcane bagasse as a novel carbon source for heterotrophic cultivation of oleaginous microalgae Schizochytrium sp. Industrial Crops and Products, vol. 121, pp. 99-105. http://dx.doi.org/10.1016/j. indcrop.2018.05.005.

NUSCH, E.A., 1980. Comparison of different methods for chlorophyll and phaeopigments determination. Archiv für Hydrobiologie, vol. 14, no. 1, pp. 4-36. http://dx.doi.org/10.1127/0003-9136.

ROCHA, O. and DUNCAN, A., 1985. The relationship between cell carbon and cell volume in freshwater algae species used in zooplankton studies. Journal of Plankton Research, vol. 7, no. 2, pp. 279-294. http://dx.doi.org/10.1093/plankt/7.2.279.

SIPAÚBA-TAVARES, L.H. and BRAGA, F.M.S., 2007. Feeding activity of Colossoma macropomum larvae (tambaqui) in fish pond with water hyacinth (Eichhornia crassipes) fertilizer. Brazilian Journal of Biology $=$ Revista Brasileira de Biologia, vol. 67, no. 3, pp. 454-466. http://dx.doi.org/10.1590/S151969842007000300010 .

SIPAÚBA-TAVARES, L.H. and ROCHA, O., 1993. Largescale cultivation of plankton for feeding larvae and fish fry: I-Algae green. Biotemas, vol. 6, no. 1, pp. 93-106. http://dx.doi. org/10.5007/ 2175-7925.

SIPAÚBA-TAVARES, L.H., FLORÊNCIO, T. and SCARDOELITRUZZI, B., 2018. Aquaculture biological waste as culture medium to cultivation of Ankistrodesmus gracilis (Reinsch) Korshikov. Brazilian Journal of Biology = Revista Brasileira de Biologia, vol. 78, no. 3, pp. 579-587. http://dx.doi.org/10.1590/15196984.175432. PMid:29166430. 
SIPAÚBA-TAVARES, L.H., IBARRA, L.C. and FIORESI, T.B., 2009. Ankistrodesmus gracilis (Reinsch) Korshikov (Chlorophyta) laboratory cultured in $\mathrm{CHU}_{12}$ and macrophyte with NPK media. Boletim do Instituto de Pesca, vol. 35, no. 1, pp. 111-118.

STATSOFT, 2007. Statistica: data analysis software system, version 8 . Tulsa: StatSoft, Inc.

VAN WAGENEN, J., FRANCISCI, D. and ANGELIDAKI, I., 2015. Comparison of mixotrophic to cyclic autotrophic/ heterotrophic growth strategies to optimize productivity of Chlorella sorokiniana. Journal of Applied Phycology, vol. 27, no. 5, pp. 1775-1782. http://dx.doi.org/10.1007/s10811-014-0485-1.

WEN, X., TAO, H., PENG, X., WANG, Z., DING, Y., XU, Y., LIANG, L., DU, K., ZHANG, A., LIU, C., GENG, Y. and LI, Y., 2019. Sequential phototrophic-mixotrophic cultivation of oleaginous microalgae Grasiella sp. WBG-1 in a $1000 \mathrm{~m}^{2}$ open raceway pond. Biotechnology for Biofuels, vol. 12, no. 1, pp. 27. http://dx.doi.org/10.1186/s13068-019-1367-1. PMid:30805027. 